\title{
Zinc induces shifts in microbial carbon flux in tropical coastal environments
}

\author{
E. J. Rochelle-Newall ${ }^{1,3, *}$, B. Delesalle ${ }^{2}$, X. Mari ${ }^{1}$, C. Rouchon $^{1}$, J.-P. Torréton ${ }^{1,3}$, \\ O. Pringault ${ }^{1}$
}

\author{
${ }^{1}$ UR 103, CAMELIA, Centre IRD Nouméa, BP A5, 98848 Nouméa, New Caledonia \\ ${ }^{2}$ Biologie et Ecologie Tropicale et Méditerranéenne, UMR 5244 CNRS - EPHE - UPVD, Université Via Domitia, \\ 52 avenue Paul Alduy, 66860 Perpignan, France
}

${ }^{3}$ Present address: IRD UR103, ECOLAG/UMR5119, Université Montpellier II, Case 093, 34095 Montpellier Cedex 05, France

\begin{abstract}
A great deal of research has been conducted in temperate coastal ecosystems in order to understand the effect of anthropogenic inputs on the structure and function of the system; however, despite the fact that many tropical ecosystems are subject to increasing anthropogenic pressure, including increased nutrient and contaminant inputs, less attention has been paid to tropi$\mathrm{cal}$ regions. We present the results from a series of experiments aimed at examining the effects of $\mathrm{Zn}$ on microbial carbon fluxes in a tropical coastal ecosystem. We show that Zn additions at concentrations lower than the clean water limits set by environmental protection agencies for tropical waters can result in considerable changes in microbial carbon cycling in both the structure and function of the auto- and heterotrophic compartments. We observed a reduction in the relative proportion of diatoms and a concomitant increase in the relative proportions of other phytoplankton, notably dinoflagellates. Zn contamination resulted in a 2 -fold increase in the amount of total primary production incorporated into bacterial biomass. This was concomitant with a reduction in the P:R ratio in the presence of $\mathrm{Zn}$ and ultimately resulted in a bacterially dominated, heterotrophic system. This shift in balance between production and respiration further pushes the system towards being a carbon source to the atmosphere rather than a sink. These results show that even low concentrations of $\mathrm{Zn}$ can have a negative effect on the lower levels of the food web and on carbon transfer in sensitive coastal environments.
\end{abstract}

KEY WORDS: Zn · Bacteria $\cdot$ Percentage of extracellular release - PER - Primary production · Tropical coastal systems

\section{INTRODUCTION}

Toxic contaminants are as much of an environmental and socio-economic problem as global climate change, habitat destruction and introduction of exotic species (Cloern 1996). It is therefore clear that we need to increase our understanding of the role of such toxic contaminants in coastal seas if we are to deal with future threats to these ecosystems. Much research has been conducted in order to assess the effect of high levels of contamination on various components of the higher echelons of the aquatic food web, and it is clear that toxic metals can present serious problems to both the ecosystem and human health (Fisher \& Reinfelder 1995, Peters et al. 1997, Rainbow 2002). In general, previous research has tended to focus on freshwater environments (Admiraal et al. 2000, Blanck et al. 2003, Twiss et al. 2005) or on sites that are heavily contaminated, such as those next to industrial installations (Stepanauskas et al. 2005). These studies have demonstrated that high concentrations of metals can cause significant shifts in the population structures of these systems. However, most of these studies have focused on the effects of zinc and other heavy metals on the structure and function of periphyton communities (Admiraal et al. 1999, Paulsson et al. 2000, Paulsson et 
al. 2002) and few have examined the effects of metals on phytoplankton structure and activity in pelagic systems. Thus, despite the growing knowledge on the effects of $\mathrm{Zn}$ on components of the microbial loop, little is known about the effects of low concentrations of toxic trace metals on microbial processes in sensitive, oligotrophic coastal systems such as those found in tropical environments.

The microbial loop, comprised of both primary producers and heterotrophic microbial consumers, forms an integral part of the base of the food web (Azam et al. 1983). The flow of carbon through this web is controlled (1) by the autotrophic and heterotrophic populations present and (2) by the physico-chemical characteristics of the water body, such as nutrient concentrations, dissolved organic matter (DOM) quality and quantity and the presence of contaminants (Findlay 2003). Thus, variations in both nutrients and contaminants can have a considerable effect on microbial processes (Mulrooney \& Hausinger 2003). Changes induced by metal contamination in the structure and function of phytoplankton and bacterial assemblages could potentially have non-negligible consequences on microbial carbon and nutrient cycling, which can 'echo' up the entire food chain and, hence, effect the functioning of the ecosystem.

Although many metals are essential in trace amounts, all are toxic at high concentrations (Nies 1999, Mulrooney \& Hausinger 2003). This is the case for Zn, which, at limiting concentrations, can control phytoplankton growth (Sunda \& Huntsman 1992). However, higher concentrations such as those found in areas adjacent to industrial and urban developments often lead to reductions in phytoplankton diversity and activity in freshwater streams (Blanck et al. 2003) and in heavily contaminated industrial sites (Stepanauskas et al. 2005, Baker-Austin et al. 2006). The response of the auto- and heterotrophic compartments to these toxic metals is observable both on an individual level as well as on the community level (Nayar et al. 2004). These responses can range from decreases in bacterial and primary production to cell death, all of which will effect carbon cycling in the ecosystem. Moreover, there is the question of varying tolerance between the autotrophic and heterotrophic compartments (Fleeger et al. 2003). For example, it is known that heavy metal contamination can have a positive effect on fungal activity in soils, while at the same time negatively affecting bacterial activity, at least in the short term (Rajapaksha et al. 2004). Similarly, there are also differences within a compartment. For example, Blanck et al. (2003) showed that different periphyton species have different tolerances to $\mathrm{Zn}$ contamination and Muyssen \& Janssen (2001) showed that Zn tolerance differs between phytoplankton species, at least in culture. The differing sensitivities between, as well as within, each component of the food web will lead to a cascade of changes in carbon flow. A reduction in carbon fixation will, in turn, result in a reduction in the input of autochthonous organic matter to the system, thus potentially altering bacterial carbon and nutrient uptake, leading to a relative increase in heterotrophic activity. Furthermore, even such basic changes in carbon cycling can have a fundamental effect on the ecosystem, which can be particularly important in sensitive coastal ecosystems. Inhibitory effects can be either direct (i.e. reduction in activity directly due to the toxic effects of the metal) or indirect (i.e. reduction in activity directly attributable to a reduction in bioavailable carbon or an increased availability of nutrients due to reduced competition). Moreover, both the direct and indirect effects can alter the structure, in terms of community composition, and function, in terms of carbon flow through those communities.

Here, we present results from a series of experiments examining the effects of $\mathrm{Zn}$ contamination on the functional response of natural phytoplankton and bacterial populations. These experiments were conducted in an oligotrophic tropical coral reef lagoon subject to metal inputs from both industrial and urban sources (Dalto et al. 2006). The primary objective of the present study was to evaluate the effect of the metal Zn on microbial carbon cycling, and to evaluate if there was any evidence of resistance or adaptation to metal inputs.

\section{MATERIALS AND METHODS}

Sample collection. Samples were collected from 3 stations in the coastal waters around the city of Nouméa (population 146000), New Caledonia. The first station, the industrial station (Stn Ind), is in a semienclosed bay with a nickel smelter located at the head of the bay. The second station, the urban station (Stn Urb) is located in an adjacent bay. The coast around this station is highly urbanised and at the head of the bay there is a sewage outfall that deposits minimally treated household and urban waste and runoff to the bay. Previous work (Fichez et al. 2004, Dalto et al. 2006) at this station has demonstrated relatively high

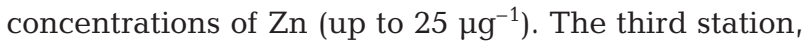
the lagoonal station (Stn Lag) is located in the coastal lagoon and is generally considered to be minimally affected by human activity (Jacquet et al. 2006). In November 2004, a second lagoon station was examined. Although this station is located offshore in the oceanic waters adjacent to the barrier reef, recent work has shown that the age of the water mass differs by on average $0.5 \mathrm{~d}$ between the 2 lagoon stations (Jouon et al. 2006, Mari et al. 2007). Each station 
was sampled at least twice between July 2005 and August 2006.

Experiments. Two sets of experiments were conducted. The first set, carried out in July 2005, examined the short-term response $(2 \mathrm{~h})$ on phytoplankton and bacterial activity to the addition of a series of zinc (Zn) concentrations. For the second set of experiments, carried out between September 2005 and March 2006, the effects of a longer-term exposure ( $7 \mathrm{~d}$ ) to this metal were examined in natural seawater microcosms.

For both experiments, samples were collected in 51 Niskin bottles from a depth of $3 \mathrm{~m}$ in order to avoid any surface effects. After sampling, the water was returned to the laboratory within $1 \mathrm{~h}$ and the samples were either put into culture or, in the case of short-term measurements, phytoplankton and bacterial production (BP) were measured. All incubation bottles were acid soaked for several days in $10 \% \mathrm{HCl}$, copiously rinsed in Milli-Q water and dried in a clean laboratory. All tubing used that came into contact with the media or the cultures was similarly cleaned. Milli-Q-rinsed Teflon tubing and new, sterile in-line filters were used (and changed each time) for the air-line filtration. Similarly, for the preparation of the media, seawater was filtered through sterile in-line filters using sterile tubing and then autoclaved in acid-cleaned and MilliQ-rinsed polycarbonate carboys.

Short-term experiments: For the short-term effect studies, 11 samples of water from each station were put into 6 polycarbonate incubation flasks (Nalgene). Each flask was subject to either no addition (control) or an addition of $\mathrm{Zn}$, corresponding to 25, 50, 100, 200, $400 \mu \mathrm{g}$ $\mathrm{l}^{-1}$. $\mathrm{Zn}$ was added in the form of $\mathrm{ZnCl}_{2}$ (Sigma). The samples were then incubated for $2 \mathrm{~h}$ in a culture chamber at in situ temperature $\left(23\right.$ to $25^{\circ} \mathrm{C}$ ) and at $130 \mu \mathrm{mol}$ photons $\mathrm{m}^{-2} \mathrm{~s}^{-1}$. At the end of this period, samples were collected for measurement of primary production and BP. Each station was tested once during July 2005.

Long-term experiments: For the long-term incubations, 21 of sample, pre-filtered through a $200 \mu \mathrm{m}$ nylon screen were added to a 251 polycarbonate carboy (Nalgene), filled with 201 of $0.2 \mu \mathrm{m}$ filtered, autoclaved, and nutrient-amended seawater. Nutrient amendments were in the form of diluted $F / 2$ nutrient media (Guillard, Sigma). The media were added to give a concentration of $2.2 \mu \mathrm{mol} \mathrm{l^{-1 }}$ nitrogen, which corresponds to the concentrations observed at Stns Urb and Ind (Jacquet et al. 2006), and an addition of phosphate of $0.09 \mu \mathrm{mol} \mathrm{l^{-1 }}$. The cultures were then incubated for $72 \mathrm{~h}$ in a $14: 10 \mathrm{~h}$ light:dark cycle at 23 to $27^{\circ} \mathrm{C}$, corresponding to the in situ seawater temperatures. The culture was aerated with $0.2 \mu \mathrm{m}$-filtered air throughout the incubation. After $3 \mathrm{~d}$ of stabilisation, the samples were divided into five 11 polycarbonate incubation flasks and incubated in batch cultures. To 3 of the flasks 1, 5 or $25 \mu \mathrm{g} \mathrm{l}^{-1}$ of $\mathrm{Zn}$ was added; only one concentration of metal was tested at a time. We therefore had 3 replicate incubations of the same metal concentration plus the replicate controls without $\mathrm{Zn}$ addition. In the incubation series in which 3 concentrations of metal were tested (January and March 2006, see Table 2), we used fifteen 11 flasks, 3 of which received $1 \mu \mathrm{g} \mathrm{l}^{-1}$ of $\mathrm{Zn}$, a further 3 received $5 \mu \mathrm{g} \mathrm{l^{-1 }}$ of $\mathrm{Zn}$ and to another 3 bottles $25 \mu \mathrm{g} \mathrm{l}^{-1}$ of $\mathrm{Zn}$ was added; the 6 remaining flasks received no metal addition and were incubated in parallel with the metal additions as controls. The highest level of $\mathrm{Zn}$ was not tested at the lagoon station. Various concentrations of Zn were used in order to determine if there was a threshold value for Zn tolerance and to take into account the high variability of Zn concentrations previously observed in the bays (Fichez et al. 2004, Dalto et al. 2006, Migon et al. 2007). Metals, along with the nutrients, were added daily for the first $5 \mathrm{~d}$, with the control flasks receiving only nutrients. Samples were collected after 0, 48, 96 and, $168 \mathrm{~h}$ for measurement of dissolved and particulate primary production and BP. Chlorophyll a (chl a) concentration was measured daily.

Primary and bacterial production and respiration. Primary production (dissolved primary production [DPP] and particulate primary production [PPP]) was measured using $\mathrm{NaH}^{14} \mathrm{CO}_{3}$ following the method of Rochelle-Newall et al. (2008). Briefly, water samples $(63 \mathrm{ml})$ were inoculated with $1.2 \mathrm{MBq}$ of $\mathrm{NaH}^{14} \mathrm{CO}_{3}$ (Perkin-Elmer) and incubated in the same incubator adjacent to the cultures. After $4 \mathrm{~h}$ incubation, always between 08:00 and 13:00 h, samples were carefully filtered at low vacuum pressure onto $0.4 \mu \mathrm{m}$ polycarbonate filters (Whatman Cyclopore). After acidification and drying of the filters $\left(24 \mathrm{~h}\right.$ at $\left.45^{\circ} \mathrm{C}\right), 5 \mathrm{ml}$ of scintillation cocktail (Ultima Gold, Packard Instruments) was added. The amount of ${ }^{14} \mathrm{C}$ incorporated into the particulate phase (PPP) was calculated using an inorganic carbon concentration of $25700 \mu \mathrm{g} \mathrm{C} \mathrm{l}^{-1}$ (Marañón et al. 2004). For the DPP measurement, duplicates of $5 \mathrm{ml}$ of filtrate were collected, acidified with $100 \mu \mathrm{l}$ of $5 \mathrm{~mol} \mathrm{l}^{-1}$ $\mathrm{HCl}$ and left for $12 \mathrm{~h}$ on a horizontal agitator table. After acidification, $15 \mathrm{ml}$ of scintillation cocktail (Ultima Gold XR, Packard Instruments) was added and the samples counted using a Packard Tri-Carb (1600TR) Liquid Scintillation Counter. Quench correction was performed using ${ }^{14} \mathrm{C}$ external standards with the transformed Spectral Index method (tSIE, Packard Instruments). For the radioactivity measurements, we consider that in order for the production rate to be significant there should be a ratio of at least 3 between the sample and the dark blank. Total primary production (TPP) represents the sum of DPP and PPP, and the percentage of extracellular release (PER) was calculated as DPP/TPP. 
BP was measured using ${ }^{3} \mathrm{H}$-leucine, following the method of Smith \& Azam (1992). Briefly, triplicate $1.4 \mathrm{ml}$ sub-samples along with a TCA-killed control (72 $\mu \mathrm{l} 100 \%$ TCA) were incubated in the dark for $1 \mathrm{~h}$ in the presence of $40 \mathrm{nM}$ (final concentration) high specific activity ${ }^{3} \mathrm{H}$-leucine (Perkin Elmer) at the incubation temperature. At the end of the incubation period, uptake was stopped by the addition of $72 \mu \mathrm{l}$ of $100 \%$ TCA. After 4 series of centrifugation $(13000 \times g)$ and rinsing with cold $5 \%$ TCA, the incorporation of ${ }^{3} \mathrm{H}$ leucine into the particulate fraction was counted after addition of $0.5 \mathrm{ml}$ of scintillation cocktail (Ultima Gold MV, Perkin Elmer). Quench correction was performed using ${ }^{3} \mathrm{H}$ external standards as described above. Leucine uptake was converted to carbon using the conversion factor $1.55 \mathrm{~kg} \mathrm{C} \mathrm{mol}^{-1}$ leucine (Kirchman 2001).

Community respiration was measured at the end of the incubations $(168 \mathrm{~h})$ using the oxygen microelectrode technique of Briand et al. (2004). Due to a technical problem with the microelectrodes, there are no respiration measurements for Stn Ind in January 2006.

Phytoplankton abundance and pigment concentration. Chl a was measured on samples collected on GF/F filters using the method of Holm-Hansen et al. (1965). The filters were frozen $\left(-20^{\circ} \mathrm{C}\right)$ until measurement, which was always within $72 \mathrm{~h}$ and generally within $24 \mathrm{~h}$. To determine pigment composition using high performance liquid chromatography (HPLC), a volume of 200 to $300 \mathrm{ml}$ (depending on chl a concentration) was filtered onto Whatman GF/F filters which were then stored at $-80^{\circ} \mathrm{C}$ until analysis. The HPLC measurements followed the method of Van Heukelem \& Thomas (2001) with the adaptation of Hooker et al. (2005). Briefly, samples were separated using a HPLC Eclipse XDB column (Agilent Technologies) filled with a C8 stationary phase. The column temperature was $60^{\circ} \mathrm{C}$ and the photo diode array detector was set to plot chromatograms at 450,665 and $222 \mathrm{~nm}$ and to acquire visible absorbance spectra between 350 and $750 \mathrm{~nm}$.

The abundance of microalgae was estimated using inverted microscopy on the initial and final samples for each incubation. Water samples $(250 \mathrm{ml})$ were preserved in the dark with neutral formalin $(2.5 \%$, final concentration). Cell counts were carried out on the whole sample using the classic Utermöhl method with an inverted microscope (Wild M40). Counting was done at a magnification of $\times 300$, either on $1 \mathrm{~cm}^{2}$ or on three $2.5 \mathrm{~cm}$ diameters of the settling chamber, depending on algal abundance. Higher magnification $(\times 1500)$ was used for the identification of minute species when possible.

Statistical analyses. The $\mathrm{EC}_{50}$ (half-maximal effective concentration) values in the short-term incubations were determined using Eq. (1). This equation is commonly used to determine $\mathrm{EC}_{50}$ values and was applied to the data using the curve fitting procedure in the SigmaPlot 10 graphical software package (Systat).

$$
y=\operatorname{Min}+\frac{\operatorname{Max}-\operatorname{Min}}{\left[1+\left(\frac{C}{E_{50}}\right)^{\text {Hill slope }}\right]}
$$

where $y$ represents the activity measured at concentration $C$, Min and Max represent the minimum and the maximum observed activity values, respectively, and Hill slope is the largest absolute value of the slope of the curve. The Min value was assumed to be 0 since, in all cases, complete inhibition of the activity was not observed.

In the long-term experiments, significant differences between the replicate treatments and controls were tested using the Statgraphics Centurion XV software package (Statpoint). A 2-way analysis of variance (ANOVA), with time and treatment as fixed factors, was used to test the significance of the differences between treatments in the incubations after checking that the assumptions of the ANOVA were met. When a significant difference was observed, an a posteriori test (Fisher's LSD) was used. A 1-way ANOVA was used to test for differences in the amount of photosynthetic carbon incorporated into bacterial biomass, followed by an a posteriori Fisher's LSD test.

\section{RESULTS}

\section{Short-term incubations}

In general, Zn was inhibitory at all concentrations tested during the short-term incubations (Figs. 1 \& 2). This was true for both primary production and BP, with reductions of up to $60 \%$ in PPP observed at the highest concentrations. The extrapolated concentrations, calculated from a decay model for which a decrease of $50 \%\left(\mathrm{EC}_{50}\right)$ would be observed, were (mean $\left.\pm \mathrm{SD}\right) 282$ $\pm 39,523 \pm 70$ and $620 \pm 32 \mu \mathrm{g} \mathrm{l^{-1 }}$ for Stns Ind, Lag and Urb, respectively (Table 1). Concomitant with a decrease in PPP, an increase in PER, measured as the amount of dissolved organic carbon (DOC) produced during primary production, relative to the total amount of carbon fixed, was observed for both Stns Urb and Ind. The PER rates at Stn Lag were below the detection limit.

The inhibitory effect of $\mathrm{Zn}$ on BP was observable at all 3 stations and ranged from 0 to almost $80 \%$ less than the control (Fig. 2). As with primary production, for $\mathrm{BP}$ we calculated the concentration for which $\mathrm{EC}_{50}$ would be observed. The values $( \pm \mathrm{SD})$ ranged from 147 \pm 10 and $334 \pm 32 \mu g \mathrm{l}^{-1} \mathrm{Zn}$ for Stns Urb and Ind, respectively, to over $7294 \pm 10411 \mu \mathrm{g} \mathrm{l}^{-1} \mathrm{Zn}$ for Stn Lag 

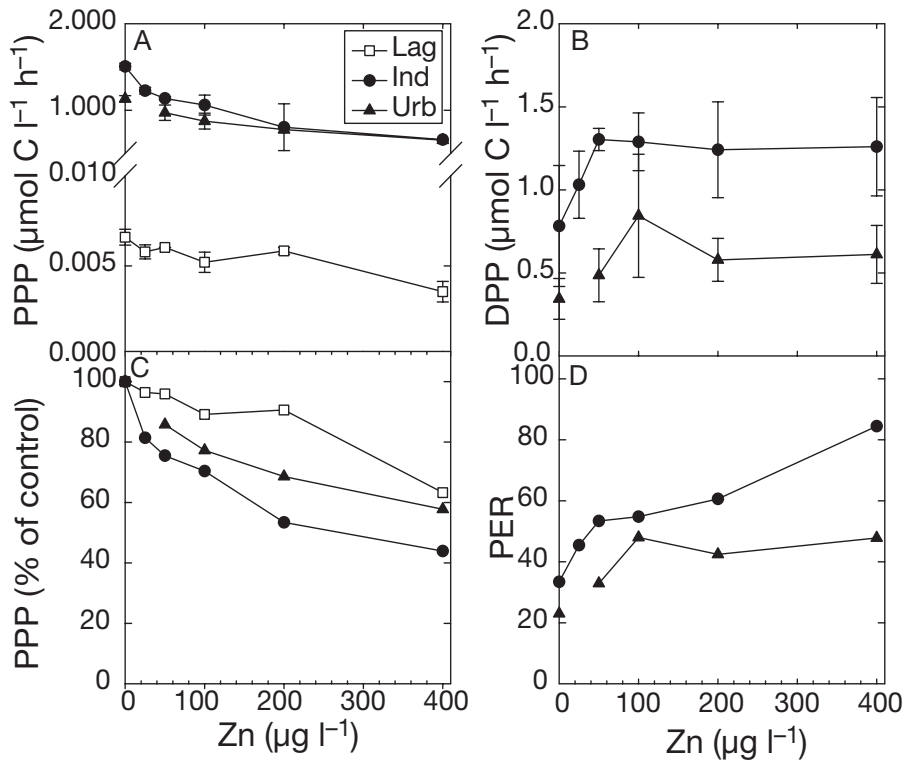

Fig. 1. Short-term effect ( $2 \mathrm{~h}$ incubation) of $\mathrm{Zn}$ on primary production (particulate and dissolved) for the 3 study stations (lagoonal station [Stn Lag], industrial station [Stn Ind] and urban station [Stn Urb]). (A) Particulate primary production (PPP); (B) dissolved primary production (DPP); (C) PPP as a percentage of the control (0 addition); (D) percentage extracellular release (PER). Error bars show mean \pm SD calculated from replicates of each measurement. DPP and PER values for Stn Lag were below the detection limit

(Table 1). The extremely high values for Stn Lag are subject to caution given the extremely low production values observed at this station (Fig. 2).

\section{Long-term incubations}

In general, in the week-long incubations the addition of $\mathrm{Zn}$ reduced the concentration of chl a relative to that of the control (Fig. 3). Moreover, the decreases in chl a biomass were both station and concentration dependent. For example, at Stn Ind, the percentage decrease in chl a increased with increasing Zn addition (Fig. 3). This was also true for Stn Lag. However, at Stn Urb, at the lowest concentrations of $\mathrm{Zn}\left(1 \mathrm{\mu g} \mathrm{l}^{-1}\right.$; Fig. 3A), there was no long-term evidence of $\mathrm{Zn}$ inhibition. This was not the case at higher $\mathrm{Zn}$ concentrations (5 and $25 \mathrm{\mu g} \mathrm{l}^{-1}$ ), for which a negative effect was observed at all stations.

In parallel with the reduction in chl a biomass, the inhibitory effects of $\mathrm{Zn}$ were also evident in PPP (Fig. 4). However, in contrast to the inhibitory effects of Zn on phytoplankton biomass, Zn did not always have an inhibitory effect on PPP. Interestingly, there was no significant effect of $\mathrm{Zn}$ addition at Stn Urb in the $5 \mu \mathrm{g}$ $\mathrm{l}^{-1}$ treatment (Fig. 4A,B) (ANOVA, $\mathrm{p}>0.05$ ). However, at the highest concentration at this station, as well as in

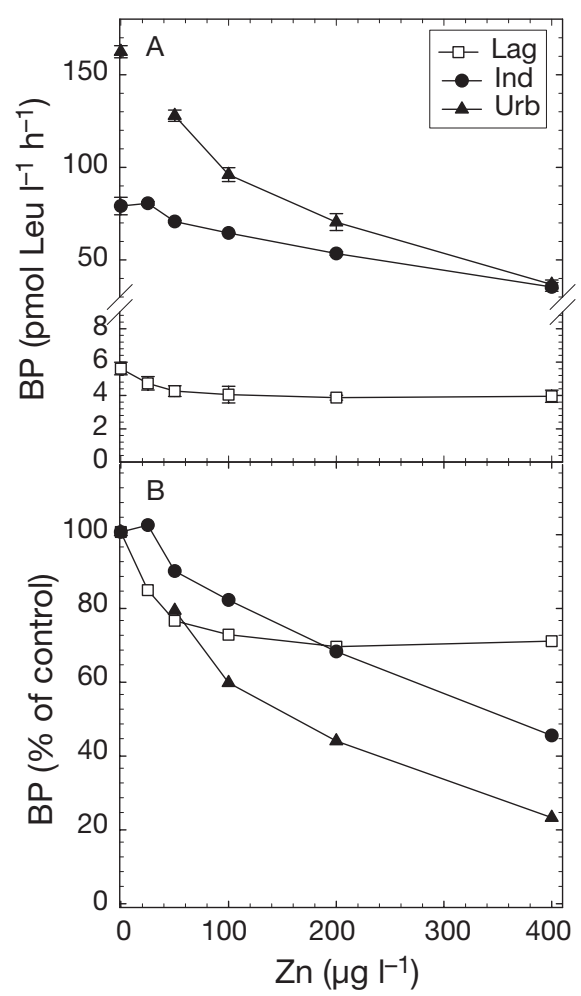

Fig. 2. Short-term effect ( $2 \mathrm{~h}$ incubation) of $\mathrm{Zn}$ on bacterial production (BP) at Stns Lag, Ind and Urb. (A) BP and (B) BP as a percentage of the control ( 0 addition). See Fig. 1 for station abbreviations

the incubations at Stn Lag, there was a significant negative effect of $\mathrm{Zn}$ addition on PPP (ANOVA, $\mathrm{p}<0.05$ ). The production of DOC during photosynthesis measured as PER in the $\mathrm{Zn}$ treatments was, in general, significantly different from that of the controls (ANOVA, $\mathrm{p}<0.05$ ). This was the case at Stns Lag and Ind and represented up to $50 \%$ of TPP as opposed to $20 \%$ in the controls (Fig. 4D,E). The only exception where no

Table 1. Half-maximal effective concentration values $\left(\mathrm{EC}_{50}\right.$

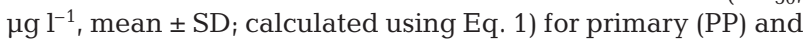
bacterial (BP), short-term experiments. Coefficient of determination $\left(R^{2}\right)$ and $p$-value for the fitting procedure of Eq. (1) are also indicated

\begin{tabular}{|lccc|}
\hline Activity & $\mathrm{EC}_{50}$ & $\mathrm{R}^{2}$ & $\mathrm{p}$ \\
\hline Stn Lag & & & \\
PP & $523 \pm 70$ & 0.942 & 0.0138 \\
BP & $7294 \pm 10411$ & 0.974 & 0.0117 \\
Stn Ind & & & \\
PP & $282 \pm 39$ & 0.994 & 0.001 \\
BP & $334 \pm 32$ & 0.993 & 0.002 \\
Stn Urb & & & \\
PP & $620 \pm 32$ & 0.999 & 0.001 \\
BP & $147 \pm 10$ & 0.998 & 0.001 \\
\hline
\end{tabular}




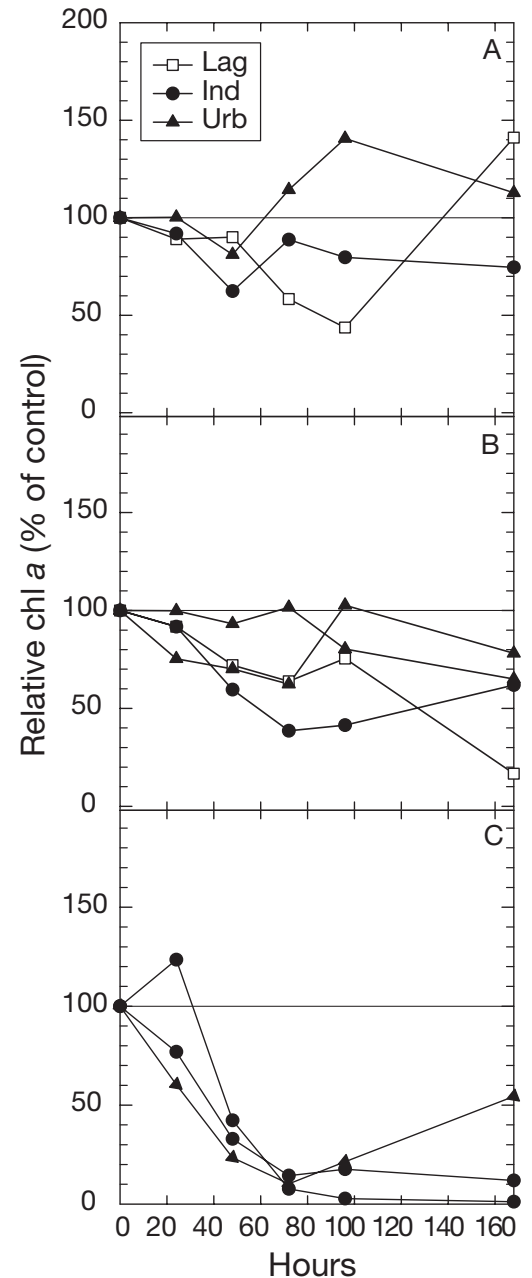

Fig. 3. Effect of $\mathrm{Zn}$ on chlorophyll a (chl a) concentration during the long-term incubations ( $7 \mathrm{~d}$ ). Values are presented as a relative percentage of the control. Horizontal line at $100 \%$ indicates no difference from the controls. Effect of $\mathrm{Zn}$ was studied twice for Stns Urb and Ind at 5 and $25 \mu \mathrm{g} \mathrm{l}^{-1}$, respectively (cf. Table 2). The highest concentration of $\mathrm{Zn}$

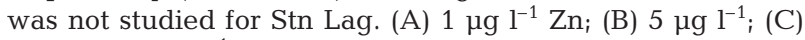
$25 \mu \mathrm{g} \mathrm{l^{-1 }}$. See Fig. 1 for station abbreviations

significant effects of $\mathrm{Zn}$ addition on PER were observed was in the $5 \mu \mathrm{g}^{-1}$ incubation at Stn Urb. At the highest concentrations of $\mathrm{Zn}$, the PER rates were over twice that of the control for both Stns Urb and Ind.

\section{Effect of zinc on bacterial production}

DOC, and therefore DOM released during photosynthesis, is the energy source for bacteria. It can be thus expected that increases in PER would lead to increases in BP. Interestingly, this did not appear to be the case in many of the long-term incubations as the changes in PER were not reflected in the differences in BP in the treatments (Fig. 5). In many (6 out of 9) cases,
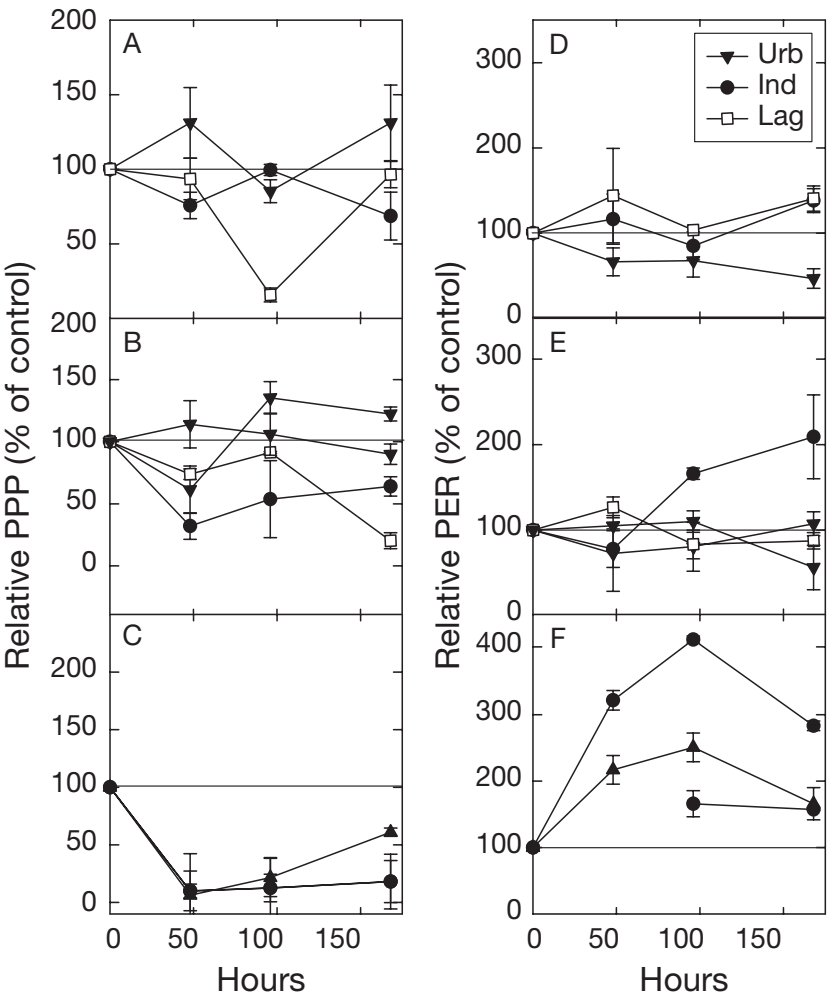

Fig. 4. Effect of $\mathrm{Zn}$ on primary (particulate and dissolved) production during the long-term incubations $(7 \mathrm{~d})$. Effect of $\mathrm{Zn}$ was studied twice for Stns Urb and Ind at 5 and $25 \mathrm{\mu g} \mathrm{l}^{-1}$, respectively (cf. Table 2). The highest concentration of $\mathrm{Zn}$ was not studied for Stn Lag. Values are presented as a percentage of the control. Horizontal line at $100 \%$ indicates no difference from the controls. Mean \pm SD are shown. $(A, D)$ $1 \mu \mathrm{g} \mathrm{l}^{-1} \mathrm{Zn}$; (B,E) $5 \mu \mathrm{g} \mathrm{l}^{-1}$; $(\mathrm{C}, \mathrm{F}) 25 \mu \mathrm{g} \mathrm{l}^{-1}$. See Fig. 1 for station abbreviations

there was no statistically significant difference between BP and the controls in the incubation (ANOVA, p > 0.05), despite large variations in PER. This was particularly evident in the highest Zn treatment, for which BP was not significantly different from the control, despite up to 2-4 fold increases in PER (ANOVA, p > 0.05). Interestingly, in both incubations at Stn Lag, there was a significant increase in BP relative to the controls, as well as in the two $5 \mu \mathrm{g} \mathrm{l}^{-1}$ addition incubations at Stn Urb (ANOVA, p < 0.05). In contrast, we did not observe a significant effect of $\mathrm{Zn}$ addition on any of the incubations from Stn Ind (ANOVA, p > 0.05). The respiration rates measured at the end of the incubations were variable and no pattern was immediately apparent (Table 2).

In order to address our objective of determining if even low concentrations of dissolved metals could induce changes in microbial carbon cycling, we calculated the percentage of TPP that is incorporated into bacterial biomass (Fig. 6). The amount of BP relative to TPP was calculated for each control and treatment at 


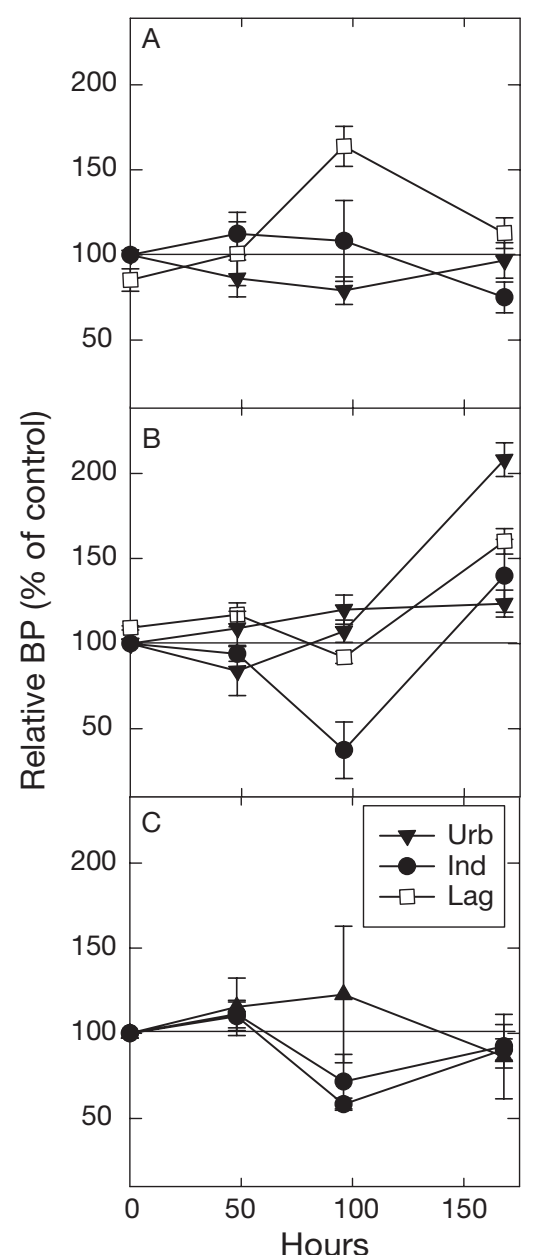

Fig. 5. Effect of $\mathrm{Zn}$ on bacterial production (BP) during the long-term incubations $(7 \mathrm{~d})$. The highest concentration was not studied at Stn Lag. Values are presented as a percentage of the control. Values $>100 \%$ indicate an increase relative to the control, thus a stimulatory effect of the $\mathrm{Zn}$ addition, with the inverse true for values $<100 \%$. (A) $1 \mu \mathrm{g} \mathrm{l}^{-1} \mathrm{Zn}_{\text {; }}$ (B) $5 \mu \mathrm{g} \mathrm{l^{-1 }}$;

(C) $25 \mu \mathrm{g} \mathrm{l^{-1 }}$. See Fig. 1 for station abbreviations

the end of each experiment. Then the relative increase in this ratio was plotted as a function of metal addition. A ratio of 1 indicates no change in the proportion of TPP being incorporated into bacterial biomass (BP) (i.e. the proportion was the same in the controls and the metal additions), whereas values higher than 1 are indicative of an increase in the amount of TPP incorporated into the heterotrophic pool. There was a statistically significant difference in the amount of carbon incorporated into bacterial biomass between the 3 treatments (ANOVA, p < 0.05). An a posterori Fisher's LSD test showed that there was a statistically significant difference between the 1 and the $5 \mu^{-1} \mathrm{l}^{-1}$ additions $(\mathrm{p}<0.05)$ and between the 1 and the $25 \mu \mathrm{g} \mathrm{l^{-1 }}$ additions $(p<0.05)$, but not between the 5 and the $25 \mu \mathrm{g} \mathrm{l}^{-1}$ additions $(\mathrm{p}>0.05)$. Thus, it appears that the

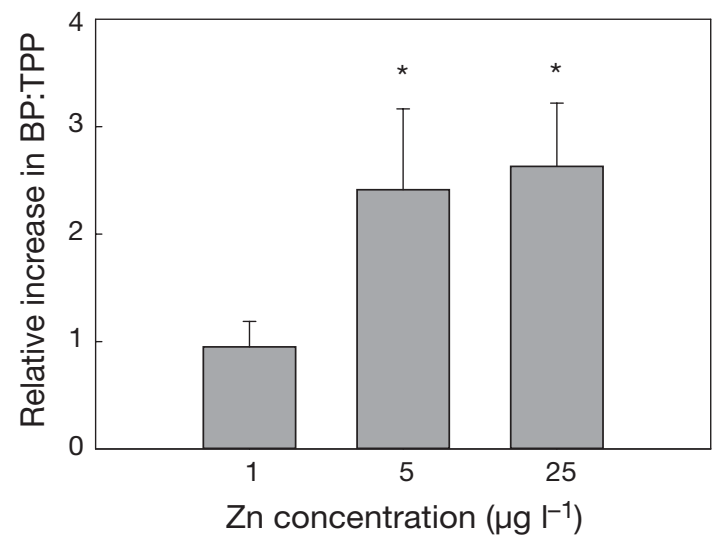

Fig. 6. Relative increase in the BP to TPP (total primary production) ratio. The amount of BP relative to TPP was calculated for each control and treatment at the end of each experiment. The relative increase in this ratio is plotted as a function of metal addition. A ratio of 1 indicates no change in the proportion of TPP being incorporated into bacterial biomass (BP), whereas values $>1$ are indicative of an increase in the amount of TPP incorporated into the heterotrophic pool. Data from all of the experiments are used. Error bars are + SE. ${ }^{*}$ : statistically significant difference from the $1 \mu \mathrm{g} \mathrm{l^{-1 }}$ treatment $(p<0.05)$

addition of $\mathrm{Zn}$ at concentrations higher than $1 \mu \mathrm{g}^{-1}$ to the incubations induced a 2-fold increase in the amount of TPP being incorporated into the bacterial pool (Fig. 6). The shift to a higher degree of heterotrophy at higher Zn concentrations is also evident in the $\mathrm{P}: \mathrm{R}$ data (Table 2). In all cases, the addition of $\mathrm{Zn}$ induced a reduction in the ratio of $P: R$, calculated from TPP and CR, thus indicating a shift towards a more heterotrophic system in the presence of $\mathrm{Zn}$.

\section{Phytoplankton diversity}

Phytoplankton diversity was also affected by the addition of $\mathrm{Zn}$. At the end of the incubations, diatom abundance was always lower in the treatments regardless of the concentration of $\mathrm{Zn}$ added, or the origin of the water sample (Fig. 7). Interestingly, there was also a net increase in the relative abundance of dinoflagellates in most of the incubations, the majority of which were Heterocapsa sp. In several of the incubations, the relative abundance of prasinophytes also increased. This was particularly the case at Stn Lag and at the highest concentration of $\mathrm{Zn}$ at the other 2 stations (data not shown).

The changes in community structure were also evident in the HPLC results (Fig. 8, Table 3). The addition of nutrients alone at Stn Lag led to a community structure at the end of the incubation that was similar to the initial community structures of the 2 bay stations (Stns Ind and Urb). The addition of $\mathrm{Zn}\left(1 \mu \mathrm{g}^{-1}\right.$; no HPLC for 
Table 2. Respiration, bacterial carbon demand and bacterial growth efficiency calculated at the end of the long-term experiments $(7 \mathrm{~d})$. The concentration of $\mathrm{Zn}$ added is indicated in parentheses $\left(\mathrm{g} \mathrm{g} \mathrm{l}^{-1}\right)$. There are no respiration values for the Ind station in January 2006. Chl a: chlorophyll a (mean \pm

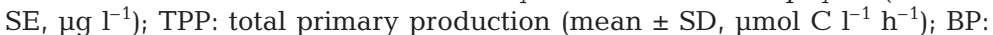

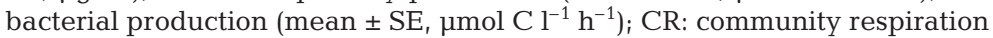

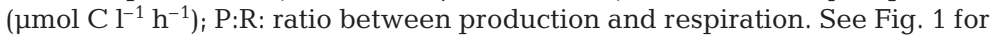
station abbreviations

\begin{tabular}{|c|c|c|c|c|c|c|}
\hline & Metal & Initial chl a & ТPP & BP & CR & $P: R$ \\
\hline \multicolumn{7}{|l|}{ Stn Ind } \\
\hline \multirow[t]{2}{*}{ Sep 05} & Control & $0.11 \pm 0.02$ & $1.8 \pm 0.68$ & $0.05 \pm 0.01$ & 5.34 & 0.33 \\
\hline & Zn (25) & $0.11 \pm 0.02$ & $0.6 \pm 0.1$ & $0.04 \pm 0.01$ & 4.42 & 0.14 \\
\hline \multirow[t]{3}{*}{ Jan 06} & Control & $0.88 \pm 0.11$ & $0.53 \pm 0.16$ & $0.04 \pm 0.02$ & & \\
\hline & Zn (5) & $0.88 \pm 0.11$ & $0.33 \pm 0.08$ & $0.05 \pm 0.01$ & & \\
\hline & Zn (25) & $0.88 \pm 0.11$ & $0.36 \pm 0.09$ & $0.05 \pm 0.01$ & & \\
\hline \multicolumn{7}{|l|}{ Stn Urb } \\
\hline \multirow[t]{2}{*}{ Feb 06} & Control & $1.46 \pm 0.17$ & $0.26 \pm 0.02$ & $0.04 \pm 0.02$ & 0.88 & 0.30 \\
\hline & Zn (5) & $1.46 \pm 0.17$ & $0.19 \pm 0.07$ & $0.04 \pm 0.01$ & 1.02 & 0.19 \\
\hline \multirow[t]{4}{*}{ Mar 06} & Control & $0.49 \pm 0.01$ & $1.95 \pm 0.30$ & $0.15 \pm 0.06$ & 3.62 & 0.54 \\
\hline & Zn (1) & $0.49 \pm 0.01$ & $2.78 \pm 0.57$ & $0.16 \pm 0.02$ & 1.21 & 2.9 \\
\hline & Zn (5) & $0.49 \pm 0.01$ & $1.64 \pm 0.13$ & $0.35 \pm 0.03$ & 1.37 & 1.2 \\
\hline & Zn (25) & $0.49 \pm 0.01$ & $1.28 \pm 0.13$ & $0.15 \pm 0.01$ & 2.43 & 0.5 \\
\hline \multicolumn{7}{|l|}{ Stn Lag } \\
\hline \multirow[t]{2}{*}{ Oct 05} & Control & $0.11 \pm 0.01$ & $0.67 \pm 0.18$ & $0.04 \pm 0.00$ & 7.93 & 0.1 \\
\hline & Zn (5) & $0.11 \pm 0.01$ & $0.20 \pm 0.05$ & $0.06 \pm 0.00$ & 7.99 & 0.03 \\
\hline \multirow[t]{2}{*}{ Nov 05} & Control & $0.13 \pm 0.01$ & $0.43 \pm 0.07$ & $0.10 \pm 0.01$ & 1.75 & 0.25 \\
\hline & Zn (1) & $0.13 \pm 0.01$ & $0.35 \pm 0.07$ & $0.11 \pm 0.01$ & 3.20 & 0.11 \\
\hline
\end{tabular}

the higher concentrations) also altered phytoplankton community structure. For example, the community structure at the end of the incubation in the $\mathrm{Zn}$ additions for Stn Lag and the controls for both Stns Ind and Urb were very similar (83.1 and $78.1 \%$, respectively; Table 3 ). Also, the high relative similarities (79.4 and $78.7 \%$ for Stns Ind and Urb, respectively) between the controls and the $\mathrm{Zn}$ additions for both Stns Urb and Ind show that the addition of $\mathrm{Zn}$ did not appear to induce a large difference in population structure, at least for the concentrations used here $\left(1 \mu \mathrm{g} \mathrm{l}^{-1}\right)$ compared to what was observed for Stn Lag (54.2\%). In summary, the population structure of the oligotrophic station was more sensitive to $\mathrm{Zn}$ addition than the 2 bay stations.

\section{DISCUSSION}

The results presented here show the complex effects of small additions of trace metals on the carbon cycling within the microbial loop. The concentrations added in these incubations are considered characteristic of what has been previously measured in the coastal waters surrounding Nouméa (Fichez et al. 2004, Dalto et al. 2006, Migon et al. 2007) and are representative of that measured in urbanised coastal areas (Baeyens et al. 1997, Buck et al. 2005). Moreover, the concentrations used were generally lower

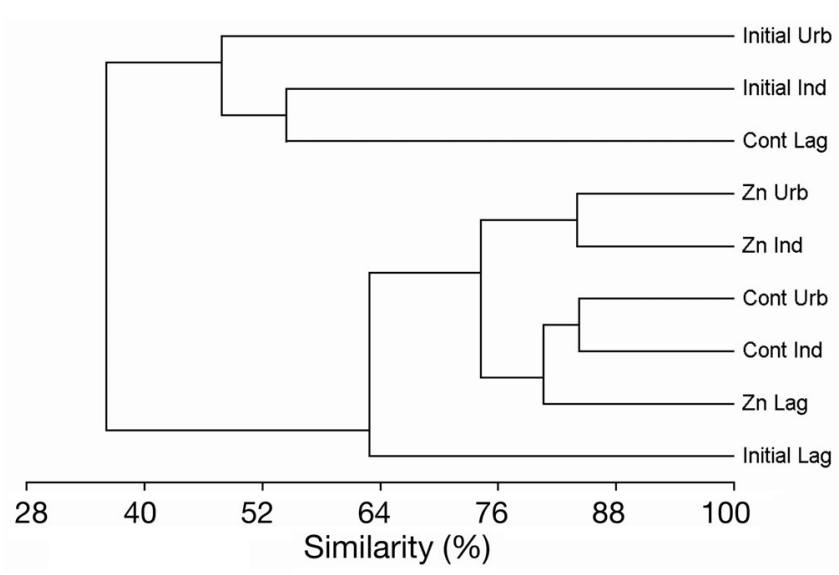

Fig. 8. Unweighted Pair Group Method with Arithmetic mean (UPGMA) dendrogram of similarity (Whittaker index) calculated from HPLC data. The same samples as in Fig. 7B are shown for ease of comparison. Zn: cultures with $\mathrm{Zn}\left(1 \mu \mathrm{g} \mathrm{l}^{-1}\right)$ and nutrient additions; Cont: control with nutrients only for the 3 sites. See Fig. 1 for station abbreviations 
Table 3. Matrix of similarity (Whittaker index) calculated from HPLC data presented in Fig. 8

\begin{tabular}{|lccccccccc|}
\hline & $\begin{array}{c}\text { Initial } \\
\text { Lag }\end{array}$ & $\begin{array}{c}\text { Cont } \\
\text { Lag }\end{array}$ & $\begin{array}{c}\text { Zn } \\
\text { Lag }\end{array}$ & $\begin{array}{c}\text { Initial } \\
\text { Ind }\end{array}$ & $\begin{array}{c}\text { Cont } \\
\text { Ind }\end{array}$ & $\begin{array}{c}\text { Zn } \\
\text { Ind }\end{array}$ & $\begin{array}{c}\text { Initial } \\
\text { Urb }\end{array}$ & $\begin{array}{c}\text { Cont } \\
\text { Urb }\end{array}$ & $\begin{array}{c}\text { Zn } \\
\text { Urb }\end{array}$ \\
\hline Initial Lag & 100.0 & & & & & & & & \\
Cont Lag & 32.3 & 100.0 & & & & & & & \\
Zn Lag & 53.4 & 54.2 & 100.0 & & & & & & \\
Initial Ind & 41.0 & 54.4 & 57.3 & 100.0 & & & & & \\
Cont Ind & 60.2 & 51.8 & 83.1 & 57.0 & 100.0 & & & & \\
Zn Ind & 66.7 & 39.1 & 69.8 & 43.6 & 79.4 & 100.0 & & & \\
Initial Urb & 16.3 & 46.4 & 24.3 & 49.4 & 24.3 & 17.6 & 100.0 & & \\
Cont Urb & 65.3 & 43.6 & 78.1 & 47.5 & 84.2 & 83.6 & 19.4 & 100.0 \\
Zn Urb & 68.6 & 30.8 & 64.7 & 35.9 & 69.5 & 84.0 & 13.9 & 78.7 & 100.0 \\
\hline
\end{tabular}

\section{Long-term effects on productivity and diversity}

Although the short-term results all showed a significant negative effect of Zn on primary production and $\mathrm{BP}$, in the longer-term incubations, the effects of the metals were more variable. However, in general, Zn was inhibitory to primary production in almost all the incubations. Moreover, by comparing the results obtained for a given concentration of metal at the different stations, there appears to be less of a negative effect on primary produc-

than the 'clean water limits' set by environmental protection agencies working in tropical waters. For example, the US State of Florida uses a concentration of $86 \mu \mathrm{g} \mathrm{l}^{-1}$ for $\mathrm{Zn}$ (FDEP 2005). However, we measured changes in the carbon flow within the microbial loop both in the short term and in the longer term using concentrations that were several times lower.

\section{Short-term effects}

In the short-term incubations, we observed a negative effect of $\mathrm{Zn}$ at all concentrations for both PPP and $\mathrm{BP}$ and a positive effect of $\mathrm{Zn}$ on DPP. We also observed a difference between the $\mathrm{EC}_{50}$ values for each station and for BP and PPP. With the exception of Stn Lag, it is interesting to note that the extrapolated concentrations are lower for BP than for primary production and that, furthermore, the apparent sensitivity to $\mathrm{Zn}$ varies as a function of the station, although the order of sensitivity is not the same for both BP and primary production (Table 1). In other words, it appears that at Stn Ind, primary production was more sensitive to $\mathrm{Zn}$ than at Stn Urb, whereas the inverse was true for BP. This suggests a difference in tolerance between the 3 sites studied and between the phytoplanktonic and bacterial compartments, similar to that observed in other environments (Blanck et al. 2003, Fleeger et al. 2003). The differences between the sites might not only be due to differences in community composition, as differences between phytoplankton and bacterial community composition are known to exist between these 2 stations (Jacquet et al. 2006, J. P. Torréton unpubl.), but also to differences in tolerance within a species. Muyssen \& Janssen (2001) have shown that phytoplankton exposed to metal contamination can develop tolerance to that metal, which may well be the case in our short-term experiments, particularly at Stns Ind and Urb. tion at Stn Urb station than at Stn Lag or, interestingly, Stn Ind. The lack of negative effect of primary production at the lower concentrations of Zn at Stn Urb seems to indicate a certain capacity for those populations to adapt to the presence of this metal, similar to what was observed in the short-term incubations. The differential effect of $\mathrm{Zn}$ on primary production and chl $a$ is probably a consequence of changes in community structure and this hypothesis is supported by the changes in phytoplankton community structure in the incubations. There was a clear reduction in the abundance of diatoms in all the incubations with added $\mathrm{Zn}$, indicating differing sensitivities of phytoplankton groups to $\mathrm{Zn}$ addition. Concomitant with this reduction we also observed an increase in the abundance of dinoflagellates, resulting in a considerable shift in the ratio between diatoms and dinoflagellates. Such alterations in phytoplankton community structure have already been observed in contaminated freshwater ecosystems (Blanck et al. 2003, Twiss et al. 2005), but to our knowledge similar data do not exist for ecosystems similar to the one examined here.

The incubation of the communities from Stn Lag induced large changes in community structure, both in the control and in the metal addition incubations. Firstly, it is interesting to note that an addition of nutrients to Stn Lag resulted in a community structure that was more similar to that observed initially at the 2 coastal bay stations (54.4 and $46.4 \%$ ) than at Stn Lag $(32.3 \%$; Table 3$)$. In other words, the addition of nutrients at the oligotrophic station resulted in a community structure that was more characteristic of a eutrophic bay station. Secondly, the addition of low concentrations of Zn $\left(1 \mu \mathrm{g} \mathrm{l}^{-1}\right)$ at Stn Lag resulted in a community structure at the end of the experiment that was also highly similar to the structure in the controls of the 2 bay stations at the end of the experiment. Interestingly, the addition of small amounts of $\mathrm{Zn}$ in the incubations carried out at Stns Ind and Urb did not result in a large change in community structure. Whether or not this is 
evidence of a tolerance to $\mathrm{Zn}$ is debatable and requires further testing in order to determine the role played by this metal in structuring phytoplankton communities, as it has been shown in freshwater environments that Zn can be more toxic to picophytoplankton communities than to the larger size classes (Twiss et al. 2005). This difference in tolerance can be explained by a higher cell surface area to volume ratio for the picophytoplankton, leading to a higher accumulation of metal than the other algae (Miao et al. 2005). It is known that the abundance of picophytoplankton at Stn Lag is higher than at the other 2 stations (Jacquet et al. 2006) and it is easy to envisage that the loss of the picophytoplankton as a consequence of $\mathrm{Zn}$ addition would result in a community structure different from a noncontaminated situation.

It has been shown for other phosphorus-limited sites (Twiss et al. 2005) that a limitation in phosphate can exacerbate the toxicity effects of Zn. However, given the fact that these systems are not generally considered to be phosphorus limited (Jacquet et al. 2006) and that nutrients were added daily, it is difficult to evaluate this interaction. Nevertheless, it is clear that even small increases in $\mathrm{Zn}$ concentrations can induce considerable changes in the phytoplankton community structure.

\section{Consequences on the functioning of the microbial loop}

The quality of DOM released by phytoplankton is known to vary with growth stage, with species and in response to the presence of contaminants (e.g. Zhou \& Wangersky 1989, Norrman et al. 1995, Biersmith \& Benner 1998, Wells 2002). Given that DOM has high chelating properties for metals, this may be a strategy to remove the contaminant from the cells (Wells 2002). In general, the relative proportions of TPP represented by PPP and DPP shifted in the presence of metals, with DPP being higher than in the controls, as indicated by the higher PER values. Thus, although Zn had a significant negative effect on TPP by reducing the total amount of carbon fixed, it also induced a shift in the proportion of carbon released into the dissolved pool. A similar shift in DOM production has been observed as a response to perturbations such as an increase in temperature (Morán et al. 2006). However, whether it was the $\mathrm{Zn}$ itself that induced an increase in organic matter release or whether it is an indirect effect of the change in phytoplankton population is difficult to determine.

The differences between short- and long-term incubations provide some insight into how the system responds to elevated episodic inputs of contaminants and to long-term chronic inputs. In our longer-term incubation dataset we observed little, if any, inhibition of BP in the metal treatments compared to the control incubations, in contrast to that observed in the shortterm incubations. If we consider the apparent shortterm negative effect of $\mathrm{Zn}$ on bacterial activity and the apparent lack of negative effect on bacterial activity in the longer-term experiments, it is probable that a change in either community or gene expression occurred. Bacteria are known to possess Zn-resistance mechanisms (Nies 2003) and recent work from the sediments of Stn Urb has proposed the presence of Znresistant bacterial populations during some periods of the year (Viret et al. 2006, Pringault et al. 2008). However, whether this is the case in the water column remains to be elucidated. Finally, although BP and phytoplankton DOM production are often tightly coupled (Morán et al. 2002), it has been shown that in this environment, the degree of coupling is not always high, particularly at the coastal sites examined (Renaud et al. 2005, Rochelle-Newall et al. 2008); this may well explain why we did not observe a correlation between bacterial and phytoplankton activity and is supported by the fact that DOM at these coastal sites is considered to be relatively non-reactive and has a relatively high residence time (Mari et al. 2007). Thus, it is probably a combination of higher nutrient availability and an adapted community structure that explains why BP was not negatively influenced by metal addition.

The coastal zone plays an important role in the global carbon cycle and any changes in its function will have a significant effect on the carbon fluxes of the oceans (Borges 2005). In the present study, we show that even small concentrations of metals can effect the transfer of carbon between the auto- and heterotrophic compartments. We calculated the relative amount of photosynthetic carbon that goes into bacterial biomass production and show that although low concentrations of $\mathrm{Zn}$ do not induce significant changes in the relative proportion of $\mathrm{BP}$, higher concentrations of $\mathrm{Zn}$ resulted in a 2 -fold increase. This is a direct reflection of the fact that the amount of algal organic carbon produced is reduced, but the amount of carbon incorporated into bacterial biomass remains the same as in the noncontaminated control. Therefore, the presence of $\mathrm{Zn}$ increases the transit of carbon through the bacterial pool and, thus, increases the importance of the microbial loop and hence the recycling of DOM. This change within the heterotrophic compartment is paralleled by a general decrease in the balance between production and respiration. We do not have separate measurements of bacterial and phytoplankton respiration and so it is difficult to determine whether or not there was a relative increase in phytoplankton respiration or if 
there was an increase in bacterial respiration. Nevertheless, it is clear that the addition of $\mathrm{Zn}$ induced a reduction in TPP without a corresponding change in community respiration, further shifting the system towards net heterotrophy.

Many tropical coastal ecosystems are surrounded by highly oligotrophic waters and so it is clear that any shift in the production to respiration balance in the coastal system may have more far reaching implications in terms of carbon export to the open ocean. Although the application of these results to in situ populations needs to be done with caution, it appears that at least in this environment, the presence of zinc leads to changes in microbial carbon flux by inducing a shift in phytoplankton community structure. This change, combined with a shift towards increased net heterotrophy, results in a system that is a source of $\mathrm{CO}_{2}$ to the atmosphere and not a sink. This in turn will result in a system that has reduced export to higher trophic levels and to the surrounding oligotrophic ocean.

Acknowledgements. We thank Ben Moreton for invaluable discussion on the concentrations of metals in the coastal zone. We thank the editor and 2 anonymous reviewers for their comments that greatly improved a previous version of the manuscript. This research was financed by the PNETOX program of the French Ministry for Ecology and Sustainable Development (Ministère de l'Ecologie et du Développement Durable), the Ministry of Overseas Territories (Ministère de l'Outre Mer) and the Institut de Recherche pour le Développement (IRD). This study also benefited from a synergy with the ECCO national program (France).

\section{LITERATURE CITED}

Admiraal W, Blanck H, Buckert-De Jong M, Guasch H and others (1999) Short-term toxicity of zinc to microbenthic algae and bacteria in a metal polluted stream. Water Res 33:1989-1996

Admiraal W, Barranguet C, van Beusekom SAM, Bleeker EAJ and others (2000) Linking ecological and ecotoxicological techniques to support river rehabilitation. Chemosphere 41:289-295

Azam F, Fenchel T, Field JG, Gray JS, Meyer Reil LA, Thingstad F (1983) The ecological role of water-column microbes in the sea. Mar Ecol Prog Ser 10:257-263

Baeyens W, Elskens M, Gillain G, Goeyens L (1997) Biogeochemical behaviour of $\mathrm{Cd}, \mathrm{Cu}, \mathrm{Pb}$ and $\mathrm{Zn}$ in the Scheldt estuary during the period 1981-1983. Hydrobiologia 366:15-44

Baker-Austin C, Wright MS, Stepanauskas R, McArthur JV (2006) Co-selection of antibiotic and metal resistance. Trends Microbiol 14:176-182

Biersmith A, Benner R (1998) Carbohydrates in phytoplankton and freshly produced dissolved organic matter. Mar Chem 63:131-144

Blanck H, Admiraal W, Cleven R, Guasch H and others (2003) Variability in zinc tolerance, measured as incorporation of radio-labeled carbon dioxide and thymidine, in periphyton communities sampled from 15 European river stretches. Arch Environ Contam Toxicol 44:17-29
Borges AV (2005) Do we have enough pieces of the jigsaw to integrate $\mathrm{CO}_{2}$ fluxes in the coastal ocean? Estuaries 28:3-27

Briand E, Pringault O, Jacquet S, Torréton JP (2004) The use of oxygen microprobes to measure bacterial respiration for determining bacterioplankton growth efficiency. Limnol Oceanogr Methods 2:406-416

Buck NJ, Gobler CJ, Sañudo-Wilhelmy SA (2005) Dissolved trace element concentrations in the East River-Long Island Sound System: relative importance of autochthonous versus allochthonous sources. Environ Sci Technol 39:3528-3537

Cloern JE (1996) Phytoplankton bloom dynamics in coastal ecosystems: a review with some general lessons from sustained investigation of San Francisco Bay, California. Rev Geophys 34:127-168

> Dalto AG, Gremare A, Dinet A, Fichet D (2006) Muddybottom meiofauna responses to metal concentrations and organic enrichment in New Caledonia South-West Lagoon. Estuar Coast Shelf Sci 67:629-644

FDEP (2005) Technical report: development of clean-up target levels (CTLs). Florida Department of Environmental Protection, Gainesville, FL

Fichez R, Hédouin L, Pringault O, Thébault J, Viret H, Warnau M (2004) Caractéristiques physico-chimiques des eaux et bioaccumulation des métaux: Rapport IRD-Goro Nickel. IRD-Goro, Nouméa

Findlay S (2003) Bacterial response to variation in organic matter. In: Findlay $\mathrm{S}$, Sinsabaugh RL (eds) Aquatic ecosytems: interactivity of dissolved organic matter. Academic Press, Amsterdam, p 363-379

Fisher NS, Reinfelder JR (1995) The trophic transfer of metals in marine systems. In: Tessier A, Turner DR (eds) Metal speciation and bioavailability in aquatic systems. John Wiley, Chichester, p 363-406

Fleeger JW, Carman KR, Nisbet RM (2003) Indirect effects of contaminants in aquatic ecosystems. Sci Total Environ 317:207-233

Holm-Hansen O, Lorenzen CJ, Holmes RW, Strickland JDH (1965) Fluorimetric determination of chlorophyll. Rapp P-V Réun Cons Int Explor Mer 30:3-15

Hooker SB, Van Heukelem L, Thomas CS, Claustre H, Ras J, Barlow RG, Sessions H (2005) The second SeaWiFS HPLC analysis round-robin experiment (SeaHARRE-2). Report No.26: NASA/TM-2005-212785 NASA, Greenbelt, MD

> Jacquet S, Delesalle B, Torréton JP, Blanchot J (2006) Responses of the phytoplankton communities to increased anthropogenic influences (Southwestern Lagoon, New Caledonia). Mar Ecol Prog Ser 320:65-78

Jouon A, Douillet P, Ouillon S, Fraunié P (2006) Calculations of hydrodynamic time parameters in a semi-opened coastal zone using a 3D hydrodynamic model. Cont Shelf Res 26:1395-1415

Kirchman D (2001) Measuring bacterial biomass production and growth rates from leucine incorporation in natural aquatic environments. Methods Microbiol 30:227-237

Marañón E, Cermeño P, Fernández E, Rodríguez J, Zabala L (2004) Significance and mechanisms of photosynthetic production of dissolved organic carbon in a coastal eutrophic ecosystem. Limnol Oceanogr 49;1652-1666

Mari X, Rochelle-Newall E, Torréton JP, Pringault O, Jouon A, Migon C (2007) Water residence time: a regulatory factor of the DOM to POM transfer efficiency. Limnol Oceanogr 52:808-819

> Miao AJ, Wang WX, Juneau P (2005) Comparison of Cd, Cu, and $\mathrm{Zn}$ toxic effects on four marine phytoplankton by pulse-amplitude-modulated fluorometry. Environ Toxicol Chem 24:2603-2611 
Migon C, Ouillon S, Mari X, Nicolas E (2007) Geochemical and hydrological constraints on the distribution of trace metal concentrations in the lagoon of Nouméa, New Caledonia. Estuar Coast Shelf Sci 74:756-765

Morán XAG, Estrada M, Gasol JM, Pedrós-Alió C (2002) Dissolved primary production and the strength of phytoplankton bacterioplankton coupling in contrasting marine regions. Microb Ecol 44:217-223

Morán XAG, Sebastian M, Pedrós-Alió C, Estrada M (2006) Response of Southern Ocean phytoplankton and bacterioplankton production to short-term experimental warming. Limnol Oceanogr 51:1791-1800

Mulrooney SB, Hausinger RP (2003) Nickel uptake and utilization by microorganisms. FEMS Microbiol Rev 27: 239-261

> Muyssen BTA, Janssen CR (2001) Zinc acclimation and its effect on the zinc tolerance of Raphidocelis subcapitata and Chlorella vulgaris in laboratory experiments. Chemosphere 45:507-514

Nayar S, Goh BPL, Chou LM (2004) Environmental impact of heavy metals from dredged and resuspended sediments on phytoplankton and bacteria assessed in in situ mesocosms. Ecotoxicol Environ Saf 59:349-369

Nies DH (1999) Microbial heavy-metal resistance. Appl Microbiol Biotechnol 51:730-750

Nies DH (2003) Efflux-mediated heavy metal resistance in prokaryotes. FEMS Microbiol Rev 27:313-339

Norrman B, Zweifel UL, Hopkinson CS, Fry B (1995) Production and utilization of dissolved organic carbon during an experimental diatom bloom. Limnol Oceanogr 40:898-907

Paulsson M, Nystrom B, Blanck H (2000) Long-term toxicity of zinc to bacteria and algae in periphyton communities from the river Gota Alv, based on a microcosm study. Aquat Toxicol 47:243-257

Paulsson M, Mansson V, Blanck H (2002) Effects of zinc on the phosphorus availability to periphyton communities from the river Gota Alv. Aquat Toxicol 56:103-113

Peters EC, Gassman NJ, Firman JC, Richmond RH, Power EA (1997) Ecotoxicology of tropical marine ecosystems. Environ Toxicol Chem 16:12-40

Pringault O, Duran R, Jacquet S, Torréton JP (2008) Temporal variations of microbial activity and diversity in marine tropical sediments. Microb Ecol 55:247-258

Editorial responsibility: Klaus Jürgens,

Rostock, Germany
Rainbow PS (2002) Trace metal concentrations in aquatic invertebrates: why and so what? Environ Pollut 120: 497-507

> Rajapaksha RMCP, Tobor-Kaplon MA, Baath E (2004) Metal toxicity affects fungal and bacterial activities in soil differently. Appl Environ Microbiol 70:2966-2973

$>$ Renaud F, Pringault O, Rochelle-Newall E (2005) Effects of the colonial cyanobacterium Trichodesmium spp. on bacterial activity. Aquat Microb Ecol 41:261-270

Rochelle-Newall EJ, Torréton JP, Mari X, Pringault O (2008) Phytoplankton-bacterioplankton coupling in a sub-tropical South Pacific coral reef lagoon. Aquat Microb Ecol 50:221-229

Smith DC, Azam F (1992) A simple, economical method for measuring bacterial protein synthesis rates in seawater using ${ }^{3} \mathrm{H}$-leucine. Mar Microb Food Webs 6:107-114

Stepanauskas R, Glenn TC, Jagoe CH, Tuckfield RC, Lindell AH, McArthur JV (2005) Elevated microbial tolerance to metals and antibiotics in metal-contaminated industrial environments. Environ Sci Technol 39: 3671-3678

Sunda WG, Huntsman SA (1992) Feedback interactions between zinc and phytoplankton in seawater. Limnol Oceanogr 37:25-40

Twiss MR, Gouvea SP, Bourbonniere RA, McKay RML, Wilhelm SW (2005) Field investigations of trace metal effects on Lake Erie phytoplankton productivity. J Gt Lakes Res 31:168-179

> Van Heukelem L, Thomas CS (2001) Computer-assisted highperformance liquid chromatography method development with applications to the isolation and analysis of phytoplankton pigments. J Chromatogr A 910:31-49

Viret H, Pringault O, Duran R (2006) Impact of zinc and nickel on oxygen consumption of benthic microbial communities assessed with microsensors. Sci Total Environ 367: 302-311

Wells ML (2002) Marine colloids and trace metals. In: Hansell D, Carlson CA (eds) Biogeochemistry of marine dissolved organic matter. Elsevier, New York, p 367-404

Zhou X, Wangersky PJ (1989) Production of copper-complexing organic ligands by the marine diatom Phaeodactylum tricornutum in a cage culture turbidostat. Mar Chem 26: 239-259

Submitted: December 20, 2007; Accepted: May 16, 2008 Proofs received from author(s): June 23, 2008 